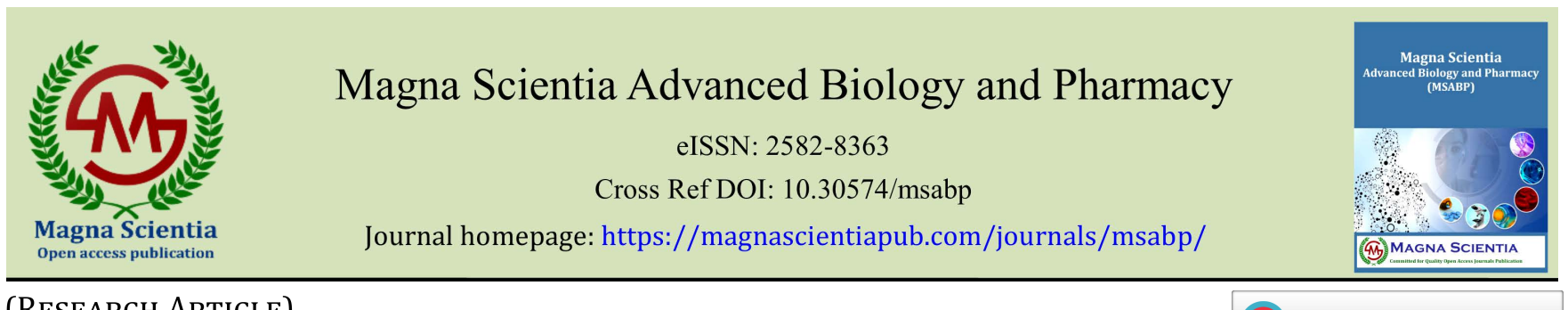

(RESEARCH ARTiClE)

Check for updates

\title{
Assessment of physicochemical, microbiological, mineral and heavy metal parameters of honey
}

\author{
Bello Muhammed Magaji *, Bamidele Joshua Awogbemi, Agnes Yemisi Asagbra, Fatunmibi Omolara Omowumi \\ and Femi Maroof Adams \\ Department of Production Analytical and Laboratory Management, Federal Institute of Industrial Research, Oshodi, PMB \\ 21023 Ikeja, Lagos State.
}

Magna Scientia Advanced Biology and Pharmacy, 2021, 04(01), 013-018

Publication history: Received on 06 October 2021; revised on 08 November 2021; accepted on 10 November 2021

Article DOI: https://doi.org/10.30574/msabp.2021.4.1.0047

\begin{abstract}
The qualities of the honey were evaluated using the following attributes Physico-chemical, Microbiological, minerals and metallic contaminants respectively. The Physico-chemical analysis revealed a moisture content of $17.45 \%$, Ash $0.64 \%$, Total solid $81.25 \%$, Fat $0.64 \%$, Protein $0.25 \%$, Fibre $0.03 \%$, Total carbohydrate $81.22 \%$, Energy value of 329.5 Kcal, pH@24.2oC, Sucrose content 5.48\%, Nitrogen content 0.004\%, Total acidity 3.45\%, Reducing sugar 61.82\%, insoluble water content $0.06 \%$, Refractive index of 1.477 , and Specific gravity of 1.234 respectively. The microbiological analysis showed a total bacterial count TBC of $7 \times 102 \mathrm{cfu} / \mathrm{g}$, Yeast count $2 \times 101 \mathrm{cfu} / \mathrm{g}$ and Mould count $2 \times 101 \mathrm{cfu} / \mathrm{g}$, which was within the national standards range by SON as $1 \times 102 \mathrm{cfu} / \mathrm{g}, 5 \times 101 \mathrm{cfu} / \mathrm{g}$, and $5 \times 101 \mathrm{cfu} / \mathrm{g}$ respectively while the Coliform count, Escherichia count, Salmonella count, Staphylococus count and Clostridium count were not detected this research. Generally, honey may contain organisms from bees, soil, air and dust that may be introduced during postharvest handling. This is evidence that honey is well preserved against bacteria so that these organisms would not survive unfavourable conditions. The mineral analysis showed the presences of potassium $\{\mathrm{K}$ ), Calcium (Ca), Sodium (Na), Magnesium (Mg), Zink (Zn), Iron (Fe) Arsenic (As) respectively with values of 70.5, 21.0, 95.0,12.0, 1.3, 1.0, and $1.0(\mathrm{Mg} / 100 \mathrm{~g})$ while Cupper and Lead were not detected.
\end{abstract}

Keywords: Physicochemical; Microbiological; Honey; Mineral

\section{Introduction}

Honey has a long history of human consumption and is used in various products like foods and beverages as a sweeteners and flavouring. Flavours of honey depend on the nectar source of various types and grades of honey that are available [1] Honey is classified by the floral source of the nectar from which it was made. [2]

Honey is a sugary and flavourful product which has been consumed as a high nutritive value food [3]. It is basically composed of a complex mixture of sugars, of which fructose and glucose account for nearly 85-95\%, and other minor substances, such as amino acids, proteins, vitamins, and lipids [3] as well as Phytochemicals (such as organic acids, vitamins, and enzymes etc),

Honey naturally contains small amounts of enzymes that are introduced by the bees during various phases of the honey manufacturing process. The predominant enzymes are diastase (amylase), invertase (a-glycosidase) and glucose oxidase. Other enzymes such as catalase and acid phosphatase are generally present in lesser amounts. [4] as well as other substances that may serve as sources of dietary antioxidants. Each of these minor constituents was known to have

\footnotetext{
${ }^{*}$ Corresponding author: Magaji Mb

Department of Production Analytical and Laboratory Management, Federal Institute of Industrial Research, Oshodi, PMB 21023 Ikeja, Lagos State.
}

Copyright (@ 2021 Author(s) retain the copyright of this article. This article is published under the terms of the Creative Commons Attribution Liscense 4.0. 
distinctive nutritional or medicinal properties and the unique blend account for the varied different applications of natural honeys. [5] Honey contains varying amount of mineral substances ranging from $0.02-1.03 \mathrm{~g} / 100 \mathrm{~g}$. The main element found in honey is potassium with an average of about one-third of the total [6]. Several investigations have shown that the trace element contents of honey depend mainly on the botanical origin of the honey [7].

The specific composition of any batch of honey will depend largely on the mix of flowers available to the bees that produced the honey. Typical honey analysis shows the following: Fructose: $38.0 \%$, Glucose: $31.0 \%$, Sucrose: $1.0 \%$, Water: $17.0 \%$, other sugars (maltose, melezitose): $9.0 \%$, Ash: $0.17 \%$, others: $3.38 \%$. [8]

The quality of honey relied to a great extent on the art of the producer in storing and blending the product [9] as well as its sensorial, taste and consistency, chemical, physical, microbiological characteristics and floral source and region of origin [2\&3] a quality product will enhance and developed the confidence that encourages return of customers due to efficient production of the product. [10].

The changes in the proportions of the original sugars is due to the enzymes present in honey, presence of over $5 \%$ of sucrose may be due to artificial feeding of the bees with the sugar during the winter or during periods of drought. [11]

The procedure for processing and storage method of a given sample of honey depends greatly on its moisture content, the probability of undesired fermentation caused by osmophilic yeasts. Honey samples with carbohydrate content < $83 \%$ and moisture content $>17.1 \%$ are easily prone to fermentation especially when they are kept at temperatures > $11^{\circ} \mathrm{C}$. A well processed honey is expected to have a long shelf life and should not ferment. The viscosity of honey is essential to its processing and it has an important link to its technological applications as a super cooled aqueous sugar solution. Honey of high quality is usually thick and viscous. The viscosity of a honey sample is a function of the composition of its sugars, water and colloid content. If the concentration of water is increased, honey becomes less viscous. Proteins and other colloidal substances increases honey viscosity, but their amount in honey may be insignificant. The percentage of fructose content in honey has also been found to affect is viscosity and rheological properties. Honeys become less viscous with increase in fructose content. The viscosity of various honey samples from different sources around the globe had been reported [12\&13].

\section{Material and methods}

\subsection{Sample Collection}

The honey sample was purchased at Mile 12 Market, close to Izala central mosques Mile 12. The sample was stored in a refrigerator prior to the analysis.

\subsection{Physico-Chemical Analysis}

\subsubsection{Proximate parameters}

(Moisture, protein, carbohydrate, fats, crude fibre and ash) were determined using the Association of Official Analytical Chemists, $15^{\text {th }}$ edition [14] method. Nitrogen content of the samples was determined by the Kjedhal method. The weight difference method was used to determine moisture and ash content while crude fat was determine using the above method with petroleum ether as solvent. The carbohydrate content was determined by calculation using the difference method \%Carbohydrate $=[100-\%($ protein + fat + moisture + ash + fiber $)]$. Digestible crude protein was calculated using the equation: \%DCP $=7.87 \times \log \mathrm{CP}-3.06$ (Hagger and Ahmed, 1970) while energy value was estimated using the equation, Energy Value $=(4 \mathrm{x}$ protein $+9 \mathrm{x}$ fat $+4 \mathrm{x}$ Carbohydrate $)$.

\subsection{2. $p H$}

The $\mathrm{PH}$ is the activity of Hydrogen ions in the water and expressed by negative logarithm to the base 10 of the $\mathrm{H}+$ ion activity in moles/L. $\mathrm{pH}$ was measured using portable $\mathrm{pH}$ meter on sample. The $\mathrm{pH}$ meter was first calibrated using buffer solutions as follows

pH 4.7 and 9.2. $\mathrm{pH}=-\log \mathrm{H}+$; or $\mathrm{H}+=(10)-\mathrm{pH}$.

\subsection{Determination of diastase activity}

A standard solution of starch, capable of developing with iodine a colour in a defined range of intensity, is acted upon by the enzyme in the honey under standard conditions. The diminution in the blue colour is measured at intervals. A 
plot of absorbance against time is used to determine the time tx required to reach absorbance $0.235 \mathrm{~nm}$. The diastase number is calculated as 300 divided by tx.

\subsubsection{Minerals composition}

This was measured by spectrometric methods using Shimadzu AA-7000 Atomic Absorption Spectrophotometer

\subsection{Microbiological Analysis}

Salmonella, Shigella agar, Violent Red bile agar, Nutrient agar, Staphylococcus agar, Potato Dextrose Agar each were prepared according to manufacturer specification. $1 \mathrm{~g}$ of sample were taking and inoculated in to $9 \mathrm{ml}$ of sterile distilled water, this was use for serial dilution $\left(10^{-1}, 10^{-3}\right.$ and $\left.10^{-5}\right)$ and was inoculated in to petri dishes using pour plate. The media of isolation were prepared on each plate and were incubated at 370c for 24-48hrs. [15].

\section{Results}

Table 1 Physico-chemical characteristics

\begin{tabular}{|l|l|l|l|}
\hline S/N & Physicochemical Parameters & Unit & Result \\
\hline 1 & Moisture content & $\%$ & 17.445 \\
\hline 2 & Ash content & $\%$ & 0.64 \\
\hline 3 & Total solid & $\%$ & 81.25 \\
\hline 4 & Fat content & $\%$ & 0.64 \\
\hline 5 & Protein & $\%$ & 0.25 \\
\hline 6 & Crude fibre & $\%$ & 0.03 \\
\hline 7 & Total carbohydrate & $\%$ & 81.22 \\
\hline 8 & Energy Value & Kcal & 29.57 \\
\hline 9 & pH@24.2 ${ }^{\circ}$ & $\%$ & 6.09 \\
\hline 10 & Sucrose content & $\%$ & 5.48 \\
\hline 11 & Nitrogen content & $\%$ & 0.04 \\
\hline 12 & Specific gravity & $\%$ & 1.2343 \\
\hline 13 & Total acidity & $\%$ & 3.45 \\
\hline 14 & Reducing Sugar & $\%$ & 61.82 \\
\hline 15 & Insoluble water content & $\%$ & 0.06 \\
\hline 16 & Refractive index & $\mathrm{NS}$ & 1.447 \\
\hline 17 & Viscosity & $\mathrm{mpa}$ & 962 \\
\hline 18 & Diastase activity & $\mathrm{DN}$ & 11 \\
\hline 19 & Lund reaction & $\mathrm{mL}$ & 2.6 \\
\hline & & Physico-chemical characteristics & \\
\hline & & & \\
\hline
\end{tabular}

Table 2 Microbiological Assessment of the sample

\begin{tabular}{|l|l|l|l|}
\hline S/N & Microbial Parameters & UNIT & RESULT \\
\hline 1 & Total Viable Count & Cfu/g & $7.0 \times 103$ \\
\hline 2 & Yeast Count & Cfu/g & $2.0 \times 101$ \\
\hline 3 & Mould Count & $\mathrm{Cfu} / \mathrm{g}$ & $2.0 \times 101$ \\
\hline 4 & Total Coliform Count & $\mathrm{Cfu} / \mathrm{g}$ & $\mathrm{ND}$ \\
\hline 5 & Escherishia Coli Count & $\mathrm{Cfu} / \mathrm{g}$ & $\mathrm{ND}$ \\
\hline 6 & Salmonella - Shigella & $\mathrm{Cfu} / \mathrm{g}$ & $\mathrm{ND}$ \\
\hline 7 & Staphylococus & $\mathrm{Cfu} / \mathrm{g}$ & $\mathrm{ND}$ \\
\hline 8 & Clostridium Count & $\mathrm{Cfu} / \mathrm{g}$ & ND \\
\hline \multicolumn{4}{|c|}{ Key, ND. Not detected } \\
\hline
\end{tabular}


Table 3 Mineral and heavy metals Composition

\begin{tabular}{|l|l|l|c|}
\hline S/N & Minerals and Metallic Contaminants & Unit & Result \\
\hline 1 & Potassium $(\mathrm{K})$ & $(\mathrm{mg} / 100 \mathrm{~g})$ & 70.5 \\
\hline 2 & Calcium $(\mathrm{Ca})$ & $(\mathrm{mg} / 100 \mathrm{~g})$ & 21.0 \\
\hline 3 & Sodium $(\mathrm{Na})$ & $(\mathrm{mg} / 100 \mathrm{~g})$ & 95.0 \\
\hline 4 & Magnesium $(\mathrm{Mg})$ & $(\mathrm{mg} / 100 \mathrm{~g})$ & 12.0 \\
\hline 5 & Zink $(\mathrm{Zn})$ & $(\mathrm{mg} / 100 \mathrm{~g})$ & 1.3 \\
\hline 6 & Iron $(\mathrm{Fe})$ & $(\mathrm{mg} / 100 \mathrm{~g})$ & 1.0 \\
\hline 7 & Arsenic $(\mathrm{As})$ & $(\mathrm{mg} / 100 \mathrm{~g})$ & $<1.0$ \\
\hline 8 & Copper $(\mathrm{Cu})$ & $(\mathrm{mg} / 100 \mathrm{~g})$ & $\mathrm{ND}$ \\
\hline 9 & Lead $(\mathrm{Pb})$ & $(\mathrm{mg} / 100 \mathrm{~g})$ & $\mathrm{ND}$ \\
\hline
\end{tabular}

\section{Discussion}

The Moisture content of $17.45 \%$ was recoded which was within the range of SON standards this variable depends on climatic factors, season of production and maturity of honey. The low moisture content helps to protect and preserved honey for longer periods of time from microbiological action. The $\mathrm{pH} 6.09 \%$ of the sample is within the national regulations by SON range from 3.42-6.10

The Ash content was $0.67 \%$ which was maximum range of acceptable limit, the flora origin of honey has been responsible for the variability in ash content as reported by Molan, [16]. Ash content presents the total inorganic minerals available in the sample after incineration [17]. The Codex Alimentarius Commission [18] specified that an ash content of not more than $0.6 \%$ for normal honey. The average acidity of honey sample analyzed in the present study was 3.45\% was in the range but very low for acceptable range in the world honey market as it ranges between 15.05 $56.7 \%$ [19-20]. Differences in honey acidity could be caused by differences in geographical condition, harvesting, and procedure storage conditions [21] which could be the reason in the case of the studied sample. The total soluble solids of the honey were $81.25 \%$ Most of the total soluble solids for honey are sugars. These account for about $80 \%$ or more of solids by weight. The percentage reducing sugars value of honey sample analyzed in the present study was $61.82 \%$ as contained in Table 1, which fulfilled the requirements of Quality and Standards Authority of Ethiopia (QSAE) [22]. The percentage sucrose content of the sample analyzed in the present study was $5.48 \%$ which was in the ranges between $1.32 \%$ to $10.98 \%$ acceptable ranges in the world honey market. The sucrose content of honey depends on botanical origin of nectar [23]. The specific gravity value of $1.234 \mathrm{~g} / \mathrm{cm}$ were obtained these values were in within the range finding of the values by El-Aab and Al-Amrony [24] $(1.2105 \mathrm{~g} / \mathrm{cm} 1.2081 \mathrm{~g} / \mathrm{cm}$ and $1.2270 \mathrm{~g} / \mathrm{cm}$ investigated for four different samples from Benghazi in Libya. The specific gravity property of honey has not been legislated by the European legislation [25]. The sucrose content of the honey sample analyzed in the present study was 5.48 which is acceptable range in the world honey market. The sucrose content of honey depends on botanical origin of nectar [26] its level should not exceed 5\% according to an International Regulatory Standards. The result of this study reveals that sucrose content of honey samples does not qualify the requirement of an International Regulatory. The higher sucrose content of honey could be the result of an early harvest of honey, in which sucrose has not been converted to fructose and glucose [27] which probably attributed to higher sucrose content

\subsection{The diastase activity}

The analysis shows an activity of 11DN. Note, that the use of enzyme activities as indicators of honey freshness is often criticized as the enzyme activities in honey depend on the intensity of the nectar flow and the amount of nectar processing by the honey bees [28]. Therefore, honey from very rich nectar sources often show high natural enzyme activities. The law diastase activity is as a result of poor and less rich nectar source.

\subsection{Microbiological analysis}

Of the honey is shown in Table 2: The total bacterial count TBC was $7 \times 10^{2} \mathrm{cfu} / \mathrm{g}$, Yeast count $2 \times 10^{1} \mathrm{cfu} / \mathrm{g}$ and Mould count $2 \times 10^{1} \mathrm{cfu} / \mathrm{g}$. This was within the national standards range by SON which was $1 \times 10^{2} \mathrm{cfu} / \mathrm{g}, 5 \times 10^{1} \mathrm{cfu} / \mathrm{g}$, and $5 \times 10^{1}$ 
cfu/g, respectively while the Coliform count, Escherichia count, Salmonella count, Staphylococus count and Clostridium count were not detected this research. Generally, honey may contain organisms from bees, soil, air and dust that may be introduced during post-harvest handling [29]. This is the evidence that honey is well preserved against bacteria so that these organisms would not survive unfavourable conditions. This result is in agreement with the report that honeys are very low in bacterial and coliform counts.

\subsection{Mineral analysis}

Showed the presences of potassium $\{\mathrm{K}$ ), Calcium (Ca), Sodium (Na), Magnesium (Mg), Zink (Zn), Iron (Fe) Arsenic (As) with values of $70.5,21.0,95.0,12.0,1.3,1.0$, and $1.0(\mathrm{Mg} / 100 \mathrm{~g})$ respectively, while Cupper and Lead were not detected. The honey is rich in minerals. The percentage mineral content is considered as a quality criterion indicating the possible botanical origin of honey [30]. The differences in mineral content majorly depend on the type of soil in which the original nectar bearing plant was located $[31,32]$.

\section{Conclusion}

This study reveals that honey possesses some nutritional quality that can be used as supplement for human daily needs. The quality and nutritional composition defend on the honey origin, and vegetation type.

\section{Compliance with ethical standards}

\section{Acknowledgments}

The authors wish to thank the Analytical marketing division, federal institute of industrial research Oshodi for providing an opportunity to carry out this work.

\section{Disclosure of conflict of interest}

All authors declared that, no conflict of interest regarding the publication of this paper.

\section{References}

[1] Vaughn MB. (2001).Pollen Contents of Honey". CAP Newsletter, 24(1):10-24.

[2] Amril A, Ladjama A.(2013). Physicochemical characterization of some multifloral honeys from honeybees Apismellifera collected in the Algerian northeast. African Journal of Food Science, 7(7): 168-173.

[3] S Gomes, LG Dias, LL. Moreira P, Rodrigues, L Estevinho.(2010). Physicochemical, microbiological and antimicrobial properties of commercial honeys from portugal," Food and chemical toxicology, 48: 544-548.

[4] White JWJr. (1978) . Honey. Advances in Food Research, 24: 288.

[5] 00 James, MA Mesubi, LA Usman, SO Yeye, KO Ajanaku, KO Ogunniran, O Ajani. (2009).Physical characterisation of some honey samples from North-Central Nigeria, International Journal of Physical Sciences, 4(9): 464-470.

[6] Bogdanov S, M Haldimann, W Luginbuhl, Gallman. (2007). Minerals in honey: Environmental, geographical and botanical aspects. Journal of Agricultural Research and Bee World. 46(4): 269 - 275.

[7] Feller-Demalsy MJ, B Vincent, F Beulieu. (1989). Mineral content and geographical origin of Canadian honeys, Apidoligie, 20(1): 77 - 91.

[8] Erguder BI, Kilicoglu SS, Namuslu M, Kilicoglu B, Devrim E, Kismet K, Durak I.(2008). Honey prevents hepatic damage Induced by obstruction of the common bile duct. World Journal of Gastroenterology. 14(23): 3729-3732.

[9] Food Chain, "Quality of honey for export," A Journal about Small-Acale Food Processing. 1995; 1: 1-16.

[10] T Geno. (2005). Application of standards in the development of apiculture," presented at the Fourth National Annual Conference of the Ethiopian Beekeepers Association, Addis Ababa, Ethiopia.

[11] White JW. (1975). Physical Characteristics of Honey a Comprehensive Survey (Ed. Crane E): Heinemann, London, 207-239.

[12] Graciela OR, Betzabé SF, Alexis F, Belkis R. (2004). Characterization of Honey Produced in Venezuela, Food Chem, 84(4): 499-502. 
[13] Hayete L, Salim O, Schweitzer P.(2007). Physicochemical Characteristics and Pollen Spectrum of Some Algerian Honeys, Food Control.,18(1): 52-58.

[14] Association of Official Analytical Chemists. (2006).Official Methods of Analysis of the Association of Official Analytical Chemists $15^{\text {th }}$ Edition, Washington D.C., USA.

[15] Tijaani A, A, Famotemi AC, Orji FA, Abimbola FB, Adams FM, Aba E.(20017). Antimicrobial susceptibility of bacteria isolated from abattoir eatery and hospital effluents International Journal of Advance Research in Biotechnological sciences , 4(1): 142-156.

[16] Molan C. (1992). The Antibacterial Activity of Honey. The Nature of the Antibacterial Activity conference. Bee World,5-28.

[17] Vanhanen L, Emmertz A, Savage G.(2011) Mineral analysis of mono-floral New Zealand honey, Food Chemistry;128: 236-240.

[18] Codex Alimentarius Commission. Draft revised standard for honey (at step 10 of the codex procedure). Codex Alimentarius Commission, FAO, Rome, Alinorm. 2001; 25: 19-26.

[19] Codex Alimentarius Committee on Sugars, Codex standard 12, revised codex standard for honey, standards and standard methods. Rome, Italy. 2001.

[20] European Union Directive (EU).(2002). European union directive 2001/110/EC of 20th, December 2001 relating to honey," Official Journal of the European Communities. Brussels, Belgium, 47-52.

[21] T Kahraman, SK Buyukunal, A Vural, SS Altunatmaz. (2010).Physico-chemical properties in honey from different regions of Turkey," Food Chemistry;123: 41-44.

[22] Quality and Standards Authority of Ethiopia (QSAE), Honey specification: Ethiopian standard, ES1202. Addis Ababa, Ethiopia. 2005.

[23] S Gobessa, E Seifu, A Bezabih (2012) Physicochemical properties of honey produced in the Homesha district of Western Ethiopia," Journal of Apicultural Science , 56: 33-40.

[24] El-Aab EM, Al-Amrony AY. (2013) Physicochemical, Heavy Metals and Phenolic compounds Analysis of Libran Honey in East Libyan Regions Journal of Science Research , 35-39.

[25] European Union Council. Council Directive (2001)/110/EC of 20 December 2001 relating to honey, Official Journal of the European Community L10: 4752.

[26] S Gobessa, E Seifu, A Bezabih.(2012) Physicochemical properties of honey produced in the Homesha district of Western Ethiopia," Journal of Apicultural Science , 56: 33-40.

[27] LC Azeredo, MAA Azeredo, SR Souza, VML Dutra. (2003).Protein contents and physicochemical properties in honey samples of Apis mellifera of different floral origins," Food Chemistry, 80: 249-254.

[28] White JW. (1994).The role of HMF and diastase assays in honey quality evaluation, Bee World.(75): 104 - 117.

[29] Jay JM. (1992). Modern food microbiology, Chapman and Hall, New York; 642.

[30] Vanhanen L, Emmertz A, Savage G.(2011) Mineral analysis of mono-floral New Zealand honey, Food Chemistry; 128: 236-240.

[31] Alvarez-Suarez J, Tulipani RS, Bertoli E, Battino M. (2010).Contribution of honey in nutrition and human health: a review. Mediterr J NutrMetab,3: 15-23.

[32] Amril A, Ladjama A.(2013). Physicochemical characterization of some multifloral honeys from honeybees Apismellifera collected in the Algerian northeast. African Journal of Food Science,7(7): 168-173. 